\title{
Chromosome Damage in Down's Syndrome Induced by Chickenpox Infection
}

\author{
MAKOTO HIGURASHI, (20) AIKO TADA, SHINOBU MIYAHARA, AND \\ MUNEHIRO HIRAYAMA \\ Department of Maternal and Child Health, University of Tokyo, Tokyo, Japan \\ HIROKI HOSHINA AND TAKASHI TAMURA \\ Department of Pediatrics, Kyorin University, Tokyo, Japan
}

\section{Extract}

Chromosomes were studied in 74-hr lymphocyte cultures from seven patients with Down's syndrome and from 12 hematologically and karyotypically normal control subjects. Six were studied before and six after chickenpox infection.

In Down's syndrome, the number of breaks per cell was $0.083 \pm$ 0.036 immediately after chickenpox infection; this was significantly greater than the number of breaks before infection, $0.03 \pm 0.008$, and also significantly greater than the number of breaks, $0.046 \pm$ 0.023, observed in control children with chickenpox. Therefore, chromosomes from patients with Down's syndrome were significantly more sensitive to breakage after chickenpox infection than those from control subjects.

The incidence of chromosome breaks in Down's syndrome 1 month after chickenpox infection fell to the level observed in the preinfection range. The present results showed that the difference between the observed and the expected values for breakage in special regions of chromosome was not significant, but that chromosome breakage was random.

\section{Speculation}

Patients with Down's syndrome show more chromosomal breakage after virus infection than do normal control subjects. This genetically determined condition may be a factor contributing to malignancy in childhood.

Recognition that viruses cause visible damage to chromosomes of human cells is relatively recent (11). There is no major body of literature on the role of viruses as mutagens as there is for radiation and chemicals, although viruses have been implicated in mutagenesis in some instances $(2,3)$. On considering the relationship between viral infection and chromosome disturbances in human cells, previous cytogenetic studies do not necessarily give much information on this interaction.

Down's syndrome is a chromosomal disorder with an increased risk of malignant disease $(8,9,14)$. It is interesting to note that cultured cells from children with Down's syndrome have a high sensitivity to various mutagens such as radiation $(5,12)$ or transformation by SV 40 virus (16). To gain further insight into the relationship between the diseases with high risk of malignancy and virus infection, we have compared the incidence of chromosomal breakage in lymphocytes from children with Down's syndrome and those from normal children before and after chickenpox infection.

\section{MATERIALS AND METHODS}

Peripheral blood samples were collected from a group of patients with Down's syndrome before, during, and 1 and 3 months after chickenpox infection. Two groups of normal children were studied as controls, one group before chickenpox infection and one group during and 1 and 3 months after infection. The ages and sexes of children included in this study are summarized in Tables 1 and 2 .

\section{PATIENTS WITH CHICKENPOX}

Blood samples were obtained from seven patients with regular trisomy 21 who ranged from 2-6 years of age and from six control children with normal karyotypes and normal hematologic findings, 2-6 years of age. Chickenpox was diagnosed clinically from the appearance on the skin and mucous membranes of successive crops of typical vesicles which was generally accompanied by a mild constitutional reaction. Children with atypical chickenpox were excluded from this study. Blood samples were collected 1-3 days after onset of the specific rash, and subsequently 1 and 3 months after infection. No individual had received either $x$-rays for diagnosis or chloramphenicol therapy in the recent past.

\section{PATIENTS BEFORE CHICKENPOX INFECTION}

In patients with Down's syndrome the frequency of chromosomal aberrations before chickenpox infection was determined from blood samples used for cytogenetic diagnosis. In the control group, blood samples were obtained from six children who were hematologically and cytogenetically normal. As stated above, these six noninfected control children were different from six control children with chickenpox because it was impossible to obtain samples from the same children both before and during infection.

\section{DETERMINATION OF CHROMOSOMAL ABERRATIONS}

Blood samples from both patients with Down's syndrome and controls were cultured for $72 \mathrm{hr}$, including a terminal incubation with colchicine, using a modification of Moorhead's method (10). In most cultures, metaphases from at least 100 lymphocytes were studied, and, when this was impossible, a minimum of 50 suitable metaphases was examined per culture. All metaphases were examined by light microscopy and records were kept of the microscope stage position for the cell, the chromosome count, and the aberrations present. Cells in mitosis were used for detailed study only if they appeared to be unbroken with well defined chromosomal morphology at high magnification. For karyotype analyses, photomicrographs were recorded from all cells in which chromosomal abnormalities were recognized. Drawings of part of some metaphases were made to study overlapping chromosomes. Both chromatid- and chromosome-type breaks were common and they were grouped in the same category, being recorded as one break. A chromatid break was scored when there was significant displace- 
Table 1. Details of cases with Down's syndrome and frequency of chromosomal aberrations

\begin{tabular}{|c|c|c|c|c|c|c|}
\hline Case & $\begin{array}{l}\text { Age, } \\
\text { yr }\end{array}$ & Sex & $\begin{array}{l}\text { Breaks } / \text { cell }^{1} \\
\text { before infection }\end{array}$ & $\begin{array}{c}\text { Interval after } \\
\text { onset of rash, days }\end{array}$ & $\begin{array}{l}\text { Breaks after }{ }^{1} \\
\text { infection }\end{array}$ & $\begin{array}{l}\text { Breaks/cell } \\
\text { after infection }\end{array}$ \\
\hline 1. $T K$ & 2 & Male & $0.032 \quad(95)$ & 3 & $8(100)$ & 0.080 \\
\hline 2. $R T$ & 6 & Female & $0.033 \quad(90)$ & 1 & $9(100)$ & 0.090 \\
\hline 3. $H K$ & 5 & Male & $0.020(100)$ & 3 & $5 \quad(95)$ & 0.053 \\
\hline 4. $K O$ & 3 & Female & $0.040(100)$ & 2 & $15(100)$ & 0.150 \\
\hline 5. $R S$ & 4 & Female & $0.030(100)$ & 2 & $7 \quad(98)$ & 0.070 \\
\hline 6. $H Y$ & 5 & Female & $0.020 \quad(50)$ & 2 & $4(100)$ & 0.040 \\
\hline 7. $Y F$ & 2 & Male & $0.036 \quad(83)$ & 1 & $10(100)$ & 0.100 \\
\hline Mean total & & & 0.030 & & $58(693)$ & 0.083 \\
\hline
\end{tabular}

${ }^{1}$ Number of cells examined appears in parentheses.

Table 2. Details of normal control subjects and frequency of chromosomal aberrations before chickenpox

\begin{tabular}{lclrc}
\hline \multicolumn{1}{c}{ Case } & $\begin{array}{c}\text { Age, } \\
\mathrm{yr}\end{array}$ & Sex & $\begin{array}{c}\text { No. of } \\
\text { breaks }\end{array}$ & $\begin{array}{c}\text { Breaks/ } \\
\text { cell }\end{array}$ \\
\hline 1. $K Y$ & 2 & Male & $3(100)$ & 0.030 \\
2. $A M$ & 6 & Female & $2(100)$ & 0.020 \\
3. $K K$ & 3 & Female & $1(100)$ & 0.010 \\
4. $E M$ & 4 & Female & $3(100)$ & 0.030 \\
5. $J I$ & 2 & Male & $2(100)$ & 0.020 \\
6. $M H$ & 6 & Female & $4(100)$ & 0.042 \\
Mean total & & & $15(595)$ & 0.025 \\
\hline
\end{tabular}

${ }^{1}$ Number of cells examined appears in parentheses.

ment of the chromatid distal to an achromatic area. The fragments were scored as breaks. Chromatid gaps or visual discontinuities of chromatin without displacement were recorded separately and were excluded from the calculations of number of breaks. The number of breaks per cell for two-hit aberrations was calculated as twice the number of dicentrics and rings, where observed. The significance of chromosome changes was estimated using standard statistical techniques, including the $t$-test. Values of probability were obtained from statistical tables. This breakage study was done in double blind fashion.

\section{RESULTS}

COMPARISON OF CHROMOSOMAL ABERRATIONS IN PATIENTS WITH DOWN'S SYNDROME BEFORE AND IMMEDIATELY AFTER INFECTION (TABLE 1)

In lymphocytes from patients with Down's syndrome infected with chickenpox, the number of breaks per cell was significantly higher than before infection $(P<0.01)$. The number of breaks per cell immediately after infection ranged from 0.040 to 0.150 with an average of 0.083 , whereas the range was from 0.020 to 0.040 with an average of 0.030 before infection. Chromosomal aberrations observed in the infected specimens included chromosome breaks of both chromatid and chromosome types. Other chromosomal aberrations were not found.

COMPARISON OF CHROMOSOMAL ABERRATIONS IN LYMPHOCYTES FROM CONTROL SUBJECTS BEFORE AND IMMEDIATELY AFTER CHICKENPOX INFECTION (TABLE 2 AND 3)

Chromosomal aberrations in control subjects immediately after infection were more frequent than before chickenpox infection, but the difference between the groups was not statistically significant $(P<0.05)$. In healthy controls the average number of breaks per cell was 0.025 compared with 0.046 in controls infected with the chickenpox virus and scored immediately after infection. Considering individual cases, three normal children (cases 1, 3,5) showed
Table 3. Details of normal control subjects and frequency of chromosomal aberrations after chickenpox

\begin{tabular}{lcllrl}
\hline \multicolumn{7}{c}{ Case } & $\begin{array}{c}\text { Age, } \\
\mathrm{yr}\end{array}$ & Sex & $\begin{array}{c}\text { Interval } \\
\text { after } \\
\text { onset of } \\
\text { rash, days }\end{array}$ & $\begin{array}{c}\text { No. of } \\
\text { breaks }^{1}\end{array}$ & $\begin{array}{c}\text { Breaks/ } \\
\text { cell }\end{array}$ \\
\hline 1. $T H$ & 6 & Female & 1 & $7(89)$ & 0.079 \\
2. $N H$ & 4 & Female & 1 & $4(100)$ & 0.040 \\
3. $H N$ & 3 & Male & 1 & $6(100)$ & 0.060 \\
4. $S T$ & 5 & Male & 1 & $2(100)$ & 0.020 \\
5. $T T$ & 2 & Male & 1 & $5(100)$ & 0.050 \\
6. $R F$ & 3 & Female & 1 & $2(82)$ & 0.024 \\
Mean total & & & & $26(571)$ & 0.046 \\
\hline
\end{tabular}

${ }^{1}$ Number of cells examined appears in parentheses.

a high frequency of chromosome breaks of between 0.05 and 0.079 breaks/cell; whereas the other three normal children (cases 2, 4,6) showed levels similar to those before infection of $0.02-0.04$ breaks/cell. These three normal children with a high frequency of chromosome breaks had no particular clinical manifestations. A few chromatid- and chromosome-type breaks were observed in cultured lymphocytes from the individuals with Down's syndrome and from the control subjects, but none of dicentrics, fragments, and interchanges was seen in either group.

TRANSITION OF CHROMOSOMAL ABERRATIONS IN PATIENTS WITH DOWN'S SYNDROME AFTER CHICKENPOX (TABLE 4)

No significant differences were found in patients with Down's syndrome. The frequency of chromosomal aberrations at 1 and 3 months after infection was compared with the levels before infection. At 1 month after infection, the number of breaks per cell in patients with Down's syndrome was 0.032 and at 3 months was 0.031 compared with 0.030 before infection.

TRANSITION OF CHROMOSOMAL ABERRATIONS IN CONTROL CHILDREN AFTER CHICKENPOX INJECTION (TABLE 5)

No significant differences were found in the frequency of chromosomal aberrations in control subjects at 1 and 3 months after infection compared with the frequency before infection. The average number of breaks per cell in the control group was 0.030 and 0.020 at 1 and 3 months after infection, respectively, compared with 0.046 before infection. In those children who showed higher frequency of chromosome breakage during chickenpox infection (cases $1,3,5$ ), the number of breaks fell to preinfection levels of 0.03-0.04 at 1 month and 0.01-0.02 at 3 months after infection.

\section{DISTRIBUTION OF BREAKS IN CHROMOSOME GROUPS}

Differences between the observed and the expected values for breakage in one particular chromosome were not observed al- 
Table 4. Transition of chromosomal aberrations after chickenpox (Down's syndrome)

\begin{tabular}{lccc}
\hline & \multicolumn{3}{c}{ Breaks/cell $^{1}$} \\
\cline { 2 - 4 } \multicolumn{1}{c}{ Case } & $\begin{array}{c}\text { Immediately } \\
\text { after } \\
\text { infection }\end{array}$ & $\begin{array}{c}1 \text { month } \\
\text { after } \\
\text { infection }\end{array}$ & $\begin{array}{c}\text { 3 months } \\
\text { after } \\
\text { infection }\end{array}$ \\
\hline 1. $T K$ & $0.080(100)$ & $0.020(100)$ & $0.030(100)$ \\
2. $R T$ & $0.090(100)$ & $0.040(100)$ & $0.030(100)$ \\
3. $H K$ & $0.053(95)$ & $0.010(100)$ & $0.020(100)$ \\
4. $K O$ & $0.150(100)$ & $0.053(100)$ & $0.030(100)$ \\
5. $R S$ & $0.070(98)$ & $0.040(100)$ & $0.040(50)$ \\
6. $H Y$ & $0.040(100)$ & $0.020(50)$ & $0.030(100)$ \\
7. $Y F$ & $0.100(100)$ & $0.044(90)$ & $0.040(100)$ \\
Mean total & $0.083(693)$ & $0.032(635)$ & $0.031(650)$ \\
\hline
\end{tabular}

${ }^{1}$ Number of cells examined appears in parentheses.

Table 5. Transition of chromosomal aberrations after chickenpox (normal control subjects)

\begin{tabular}{llcc}
\hline & \multicolumn{3}{c}{ Breaks/cell $^{1}$} \\
\cline { 2 - 4 } \multicolumn{1}{c}{ Case } & $\begin{array}{c}\text { Immediately } \\
\text { after } \\
\text { infection }\end{array}$ & $\begin{array}{c}\text { 1 month } \\
\text { after } \\
\text { infection }\end{array}$ & $\begin{array}{c}3 \text { months } \\
\text { after } \\
\text { infection }\end{array}$ \\
\hline 1. $T H$ & $0.079(89)$ & $0.030(100)$ & $0.020(100)$ \\
2. $N H$ & $0.040(100)$ & $0.030(100)$ & $0.030(100)$ \\
3. $H N$ & $0.060(100)$ & $0.040(98)$ & $0.010(50)$ \\
4. $S T$ & $0.020(100)$ & $0.020(100)$ & $0.020(50)$ \\
5. $T T$ & $0.050(100)$ & $0.040(100)$ & $0.020(50)$ \\
6. $R F$ & $0.024(82)$ & $0.020(50)$ & $0.020(350)$ \\
Mean total & $0.046(571)$ & $0.030(548)$ & \\
\hline
\end{tabular}

${ }^{1}$ Number of cells examined appears in parentheses.

though an excess of chromosome breaks was observed in the long arms of chromosome D in Down's syndrome after chickenpox infection.

\section{DISCUSSION}

There are several high risk groups for malignant diseases, such as Fanconi's anemia $(13,15)$, Bloom's syndrome, ataxia-telangiectasia and some chromosome disorders (4). Considering malignant diseases in the pediatric field, there appears to be some relationship between oncogenic, teratogenic, and mutagenic factors (7). For example, chromosomes of cultured cells from patients with Down's syndrome were reported to be highly sensitive to various mutagenic agents, such as radiation and SV 40 virus $(5,12,16)$. To gain further insight into the relation between these high risk groups and the incidence of malignant disease we have studied the effects of virus infection on the chromosomes of normal children and children with Down's syndrome.

The results of this study indicated that before infection there was little difference in the average frequency of chromosome breakage between patients with Down's syndrome and normal children. Some of Down's syndrome cells were cultured for chromosomal analyses in long intervals between first before infection and much later during infection. It is possible that this could be a source of error. However, few reports on Down's syndrome have found that the frequency of breaks depending on age in childhood is remarkably different. After chickenpox infection, the average number of chromosome breaks in cultured lymphocytes from normal children did not alter significantly, although three individuals showed higher levels of chromosome breakage which fell after recovery from infection. In patients with
Down's syndrome, the number of breaks per cell was significantly higher during chickenpox infection than before infection and also was significantly higher than in the control group during infection. In Down's syndrome, each patient showed an increase in number of breaks, ranging from two- to fourfold higher than levels before infection. This is particularly important since there is a wide range in the frequencies of chromosome breaks within the trisomic group.

The relationship between the susceptibility to chromosome damage, based on the breaks, and the severity of chickenpox infection was investigated, but no significant correlation was found in either Down's syndrome or control groups. This heterogeneity in response is in itself interesting.

The distribution of breaks in each chromosome type was checked also by comparison of the observed numbers of breaks in a given chromosome with those expected from the relative length of chromosome, assuming that breaks occur almost equally in all portions of each chromosome. In previous studies, an excess of breaks was found in chromosome 4.5 patients with infectious hepatitis and with chickenpox (1). However, the present results showed no significant difference in any particular chromosome between the observed and the expected values for breakage after chickenpox infection. The site of chromosome breaks during viral infection seemed to depend on various factors, such as heterogeneity of response to the virus and the conditions of cell culture.

Transition of chromosomal aberrations occurred with recovery from chickenpox infection. The frequency of chromosomal breakage 1 month and 3 months later was in the same range as that before infection in both Down's syndrome and normal control subjects. The chromosome damage which occurred during or immediately after infection appeared to be repaired normally within a period of 1 month.

The increased chromosomal sensitivity to chickenpox infection reflects the results of previous studies on the effects of mutagenic agents, including radiation SV 40 virus transformation and measles virus in cells with trisomy 21 (6). Comparison of the effects of measles and chickenpox infection on chromosome damage in Down's syndrome indicated that measles virus caused up to 10-fold increase in chromosome breakage, which was greater than that observed with chickenpox. It cannot be always determined that the effects of measles virus on chromosome damage are stronger than those of chickenpox virus, because the number of cases examined was restricted. However, these findings suggested that some types of virus may cause a particularly high risk of chromosome damage in Down's syndrome. The connection between the increased chromosomal sensitivity of cells with trisomy 21 towards virus infection and the susceptibility of patients with Down's syndrome to neoplasia may allow us to recognize trisomic cells to be particularly cancer prone under certain clinical or environmental conditions. On average, normal children show little susceptibility to chromosomal aberration during chickenpox infection, but evidence from the present study suggests that some individuals may have a much higher susceptibility than others. In contrast, all patients with Down's syndrome, without exception, showed increased susceptibility to chromosomal aberrations, indicating the potentially high risk of these children in response to virus infection.

\section{SUMMARY}

Chromosomal aberrations in cultured lymphocytes were studied before and after chickenpox in 7 patients with Down's syndrome and in 12 paired hematologically and karyotypically normal control subjects.

The number of breaks per cell in Down's syndrome immediately after chickenpox infection was $0.083 \pm 0.036$; this was significantly greater than $0.030 \pm 0.008$ before infection, and was also significantly greater than $0.046 \pm 0.023$ in control children with chickenpox. Therefore, chromosomes of cells from patients with 
Down's syndrome were significantly more sensitive to chickenpox infection than those from control subjects.

Chromosomal aberrations observed after infection were mainly chromosome breaks involving both chromatid and chromosome types. The present results showed that the difference between the observed and the expected values for breakage in one particular chromosome was not significant.

\section{REFERENCES AND NOTES}

1. Aula, P.: Virus-associated chromosome breaks. Amer. Acad. Sci. Ser. A. Biol. 89: 1 (1965).

2. Baumiller, R. C.: Virus induced point mutation. Nature, 214: 806 (1967)

3. Burdette, W. J., and Yoon, J. S.: Mutation, chromosomal aberrations and tumors in insects treated with oncogenic virus. Science, 155: 340 (1967).

4. German, J.: Chromosomal breakage syndromes. Birth Defect., 5: 117, (1969).

5. Higurashi, M., and Conen, P. E.: In vitro chromosomal radiosensitivity in pa tients and in carriers with non-Down's syndrome karyotypes. Pediat. Res., 6 : $514(1972)$.

6. Higurashi, M., Tamura, T., and Nakatake, T.: Cytogenetic observations in cultured lymphocytes from patients with Down's syndrome and measles. Pediat. Res., 7: 582 (1973).

7. Higurashi, M., and Conen, P. E.: In vitro chromosomal radiosensitivity in "Chromosomal breakage syndrome." Cancer, 32: 380 (1973).

8. Krivit, W., and Good, R. A.: Simultaneous occurrence of monogolism and leukemia. Report of nationwide survey. J. Dis. Childhood, 94: 289 (1957).

9. Miller, R. W., and Fraumeni, J. F., Jr.: Down's syndrome and neonatal leukemia Lancet, ii: 404 (1968).

10. Moorhead, P. S., Nowell, P. C., and Mellman, W. J., et al.: Chromosome preparations of leukocytes cultured from human peripheral blood. Exp. Cell Res., 20: 613 (1960)

11. Nichols, W. W., Levan, A., Hall, B., and Östergren, G.: Measles associated chromosome breakage. Preliminary communication. Hereditas, 48: 367 (1962).

12. Sasaki, M. S. and Tonomura, A.: Chromosomal radiosensitivity in Down's syndrome. Jap. J. Hum. Gent., 14: 81 (1969).

13. Schroeder, T. M., and Kurth, R.: Spontaneous chromosomal breakage and high incidence of leukemia in inherited disease. Blood, 37: 96 (1971)

14. Schunk, G. J., and Lehman, W. L.: Mongolism and congenital leukemia. J. Amer. Med. Ass., 155: 250 (1954).

15. Swift, M. R., and Herschhorn, K.: Fanconi's anemia inherited susceptibility to chronosome breakage in Various trissues. Ann. Intern. Med. 65:496 (1966).

16. Todaro, G. J., and Martin, G. M.: Increased susceptibility of Down's syndrome fibroblasts to transformation by SV 40. Proc. Soc. Exp. Biol. Med., 124: 1232 (1967).

17. We wish to thank Dr. J. M. Sturgess Department of Pathology, The Hospital for Sick Children, Toronto, Canada, for her advice on English expression.

18. Dr. M. Higurashi, attending cytogenetist, Department of Pediatrics, University of Tokyo, Japan.

19. This research was supported by grants from the Scientific Research

20. Requests for reprints should be addressed to: M. Higurashi, M.D., Department of Maternal and Child Health, School of Health Sciences, Faculty of Medicine, University of Tokyo, Hongo, Bunkyo-ku, Tokyo 113 (Japan).

21. Accepted for publication November 10, 1975.
Glucose

insulin

ketogenesis ketone bodies ketosis

\title{
Insulin, A Possible Regulator of Ketosis in Newborn and Suckling Rats
}

\author{
YU-YAN YEH(38) AND PAULUS ZEE
}

Laboratory of Nutrition and Metabolism, St. Jude Children's Research Hospital, Memphis, and Department of Physiology and Biophysics, University of Tennessee Center for the Health Sciences, Memphis, Tennessee, USA

Extract

A possible regulatory role of insulin in the development of ketosis in newborn and suckling rats was investigated. The average plasma concentration of total ketone bodies measured at birth was $0.414 \pm$ $0.037 \mu \mathrm{mol} / \mathrm{ml}$. Within $24 \mathrm{hr}$ after birth the level of ketones had increased to 4 times its initial value. The 3- to 4-fold increase in plasma ketones was maintained during the first 5 days of life but started to decline thereafter. Plasma insulin of newborn rats at birth $(62 \pm 8 \mu \mathrm{U} / \mathrm{ml})$ was comparable to that of fed adult rats $(85 \pm 10$ $\mu \mathrm{U} / \mathrm{ml})$. The levels decreased to $28 \mu \mathrm{U} / \mathrm{ml}$ on the first day of life and stayed low throughout the suckling period despite a tendency to increase at the time close to weaning. The capacities for ketone production in liver homogenates of suckling rats were inversely related to the levels of insulin. Administration of insulin (0.125 $\mathrm{mU} / \mathrm{g}$ body weight, im) and glucose $(1.75 \mathrm{mg} / \mathrm{g}$ body weight, ip) both suppressed plasma ketone bodies in suckling rats. Insulin administration increased plasma insulin but failed to decrease plasma glucose. Injection of glucose increased plasma insulin and glucose. Neither insulin nor glucose treatment changed the plasma levels of free fatty acids. These data suggest that a limited availability of insulin permits a high rat of ketogenesis and hence induced ketosis in newborn and suckling rats.
Speculation

Developing rats suckled by their dams derive most of their energy from the high fat and low carbohydrate content of milk. The low concentration of insulin in suckling rats not only minimizes utilization of glucose by insulin-dependent tissues but permits a rapid synthesis of ketone bodies that then serve as energy sources for extrahepatic tissues, particularly the brain. Consequently, the energy requirements of suckling rats can be met with a reduced risk of hypoglycemia. Further studies on the effect of insulin on lipolysis, fatty acid oxidation, and ketone synthesis in vitro could add to our understanding of the action of insulin in reversing ketosis of suckling rats.

Ketosis of human infants resembles that of suckling rats in many respects. In both species, plasma levels of ketone bodies are low at birth but increase rapidly after birth and remain high throughout the suckling period $(18,26,27)$. Coincident with these high levels of ketone bodies, plasma concentrations of free fatty acids are elevated during the developing stage in humans and rats $(26,27)$. The elevated fatty acid levels probably stem from the fact that newborns of all mammalian species derive most of their energy 